\title{
Process Modeling of Enzymatic Hydrolysis of Wet-Exploded Corn Stover
}

\author{
Vandana Rana $\cdot$ Diwakar Rana $\cdot$ Birgitte K. Ahring
}

Published online: 31 October 2013

(C) The Author(s) 2013. This article is published with open access at Springerlink.com

\begin{abstract}
The aim of this work was to investigate the optimal process conditions leading to high glucose yield (over $80 \%$ ) after wet explosion (WEx) pretreatment and enzymatic hydrolysis. The study focused on determining the "sweet spot" where the glucose yield obtained is optimized compared to the cost of the enzymes. WEx pretreatment was conducted at different temperatures, times, and oxygen concentrations to determine the best WEx pretreatment conditions for the most efficient enzymatic hydrolysis. Enzymatic hydrolysis was further optimized at the optimal conditions using central composite design of response surface methodology with respect to two variables: Cellic ${ }^{\circledR}$ CTec2 loading [5 to $40 \mathrm{mg}$ enzyme protein (EP)/g glucan] and substrate concentration (SC) (5 to $20 \%$ ) at $50{ }^{\circ} \mathrm{C}$ for $72 \mathrm{~h}$. The most efficient and economic conditions for corn stover conversion to glucose were obtained when wetexploded at $170{ }^{\circ} \mathrm{C}$ for 20 min with 5.5 bar oxygen followed by enzymatic hydrolysis at $20 \% \mathrm{SC}$ and $15 \mathrm{mg} \mathrm{EP} / \mathrm{g}$ glucan (5 filter paper units) resulting in a glucose yield of $84 \%$.
\end{abstract}

Keywords Corn stover - Wet explosion pretreatment . Enzymatic hydrolysis · Central composite design · Cellulose conversion

V. Rana $\cdot$ D. Rana $\cdot$ B. K. Ahring $(\triangle)$

Bioproducts, Sciences and Engineering Laboratory (BSEL),

Washington State University, 2710 Crimson Way, Richland,

WA 99354-1671, USA

e-mail:Bka@wsu.edu

$\begin{array}{ll}\text { Abbreviations } \\ \text { WEx } & \text { Wet explosion } \\ \text { EP } & \text { Enzyme protein } \\ \text { SC } & \text { Substrate concentration } \\ \text { RSM } & \text { Response surface methodology } \\ \text { CCD } & \text { Central composite design } \\ \text { HPLC } & \text { High-performance liquid chromatography } \\ \text { FPU } & \text { Filter paper units } \\ \text { ANOVA } & \text { Analysis of variance } \\ \text { SEM } & \text { Scanning electron microscopy } \\ \text { GY } & \text { Glucose yield }\end{array}$

\section{Introduction}

Corn stover is abundantly available in the Midwest of USA and can be an excellent feedstock for biofuel production because of its lower lignin content compared to woody biomass. The commercial viability of biorefineries based on corn stover has been burdened by the use of expensive enzymes needed to hydrolyze the biomass material after pretreatment $[1,2]$. It has been well established that producing higher concentration of sugars is an absolute necessity in an industrial setting as it lowers the heating requirements (lowering operating cost) and increases the volumetric efficiency (lowering capital cost) of the equipment [3]. Therefore, lowering the enzyme input and increasing the dry matter content during enzyme hydrolysis for higher cellulose conversion would be one of the most significant steps towards the direction of bioethanol production cost reduction and eventually leading to the commercialization of second-generation biorefineries based on the lignocellulosic feedstock.

Several researchers have worked on using corn stover for bioethanol production. Kaar et al. [4] used lime pretreatment 
followed by enzymatic hydrolysis at $5 \%$ substrate concentration (SC) and 20 filter paper units (FPU) (Spezyme CP and Novozym 188) and obtained $60 \%$ cellulose conversion. Kim et al. $[5,6]$ introduced ammonia recycle percolation pretreatment followed by enzyme hydrolysis at $1 \% \mathrm{SC}$ and $10 \mathrm{FPU}$ [Spezyme CP and $\beta$-glucosidase (Sigma)] and obtained $92 \%$ cellulose conversion. This concentration of solids will, however, be far from an industrial process. Bura et al. [7] used $\mathrm{SO}_{2}-$ catalyzed pretreatment followed by enzyme hydrolysis at $8 \%$ SC and 10 FPU (Spezyme CP, Novozym 188, and Multifect ${ }^{\circledR}$ Xylanase) and obtained $100 \%$ cellulose conversion. However, again, the solid concentration was far lower than that needed for operating any industrial process. Using chemicals such as sulfur could further affect the downstream processing of products; for instance, sulfur will be attached to the solid fraction that remained after sugar extraction [8]. Recently, Yang et al. [9] used steam explosion pretreatment followed by enzyme hydrolysis at $25 \% \mathrm{SC}$ and $20 \mathrm{FPU}$ (Celluclast) and obtained $85 \%$ cellulose conversion. Even though this study achieved high glucose concentrations, the amount of enzymes used was higher, affecting the applicability of the process.

In this work, we will investigate the most efficient and costeffective process conditions for producing sugars from corn stover using wet explosion (WEx) pretreatment, which only require oxygen and heat to open the structure of the biomass and which can operate at high SC $[10,11]$. Our focus will be on finding the optimal conditions producing high yields of glucose while keeping the enzyme dose low-the "sweet spot." As a first step, screening of WEx pretreatment will be performed to find the best pretreatment condition, which will be used for the optimization of enzymatic hydrolysis. The second step will be central composite design (CCD) to generate response surface, model fitting, and prediction of optimum parameters for enzymatic hydrolysis of WEx corn stover. The third step will be a scale-up study of enzymatic hydrolysis at optimized condition from lab scale to $100-\mathrm{L}$ pilot scale. In addition, we will evaluate the process economics for determining the minimum enzyme dose, which still can support a biorefinery with corn stover as raw material.

\section{Materials and Methods}

\section{Preparation of Biomass}

Corn stover with a particle size of approximately quarter inch was kindly provided by Iowa State University, Ames, IA, USA. Before pretreatment, corn stover was milled to 2-mm particle size with a Retsch cutting mill SM 200 (Retsch Inc., PA, USA) and kept at room temperature. A portion of corn stover was milled to 1-mm particle size for the compositional analysis. The compositional analysis was performed in duplicates. The moisture content of the raw corn stover was found to be $8 \%$.
Experimental Approach

Figure 1 shows the experimental setup used in the present study. The milled corn stover was pretreated using WEx at 12 different pretreatment conditions with varying temperatures (160 to $180{ }^{\circ} \mathrm{C}$ ), residence time (15 to $25 \mathrm{~min}$ ), and oxygen pressure ( 2 to 6 bar). In order to investigate the efficiency of pretreatment, enzymatic digestibility test was conducted with Cellic ${ }^{\circledR} \mathrm{CTec} 2$ (40 mg enzyme protein (EP)/g glucan) on all 12 pretreatment slurries. Sugars, sugar degradation products, and other fermentation inhibitors [hydroxymethylfurfurals (HMFs), furfural, and acetate] released during pretreatment or after enzymatic hydrolysis were analyzed using high-performance liquid chromatography (HPLC). Based on the sugar yield and the concentration of inhibitors, the optimal pretreatment condition was determined and used for finding the minimal enzyme dose needed for obtaining at least $80 \%$ of the potential cellulose conversion from the biomass. This selected pretreatment was referred as the platform WEx pretreatment.

The enzymatic hydrolysis study to optimize the enzyme dosage was performed in shake flasks on the platform WExpretreated sample using varying SCs (5 to $20 \%$ ) and enzyme loading (5 to $40 \mathrm{mg} \mathrm{EP} / \mathrm{g}$ glucan). Test of two parameters resulted in 14 experimental runs. The amount of free sugars released after these 14 enzymatic hydrolysis runs was analyzed using HPLC. Response surface methodology (RSM) was adopted to determine the optimal hydrolysis condition. Finally, the results for the optimal enzyme dose study were checked in a 100-L pilot-scale test at the optimal conditions (SC and enzyme loading) and the effect on the ultrastructure was followed using scanning electron microscopy to evaluate the changes done to the biomass during enzymatic hydrolysis. Finally, we analyzed the process economics to substantiate the effect of optimization study on the overall cost reduction of ethanol.

\section{Measurement of Protein Assay and Cellulase Activity}

The protein concentration of Cellic ${ }^{\circledR} \mathrm{CTec} 2$ (kindly provided by Novozymes, Franklinton, NC, USA) was determined using standard Pierce ${ }^{\circledR}$ BCA Protein Assay Kit (Thermo Scientific, Waltham, MA, USA). The protein concentration in Cellic ${ }^{\circledR}$ CTec2 was measured as $210 \mathrm{mg} / \mathrm{mL}$ of enzyme. Filter paper activity of Cellic ${ }^{\circledR}$ CTec2 was measured according to enzyme activity assay [12]. The cellulolytic activity of concentrate was determined as $74 \mathrm{FPU} / \mathrm{mL}$.

Selection of Platform WEx Pretreatment Parameters

\section{WEx Pretreatment of Corn Stover}

Corn stover was pretreated by WEx in a pilot plant at Washington State University as previously described [13]. The 12 different conditions used for the WEx pretreatment 
Fig. 1 Schematic of experimental methodology. The line number is shown within the circle and indicates the step order

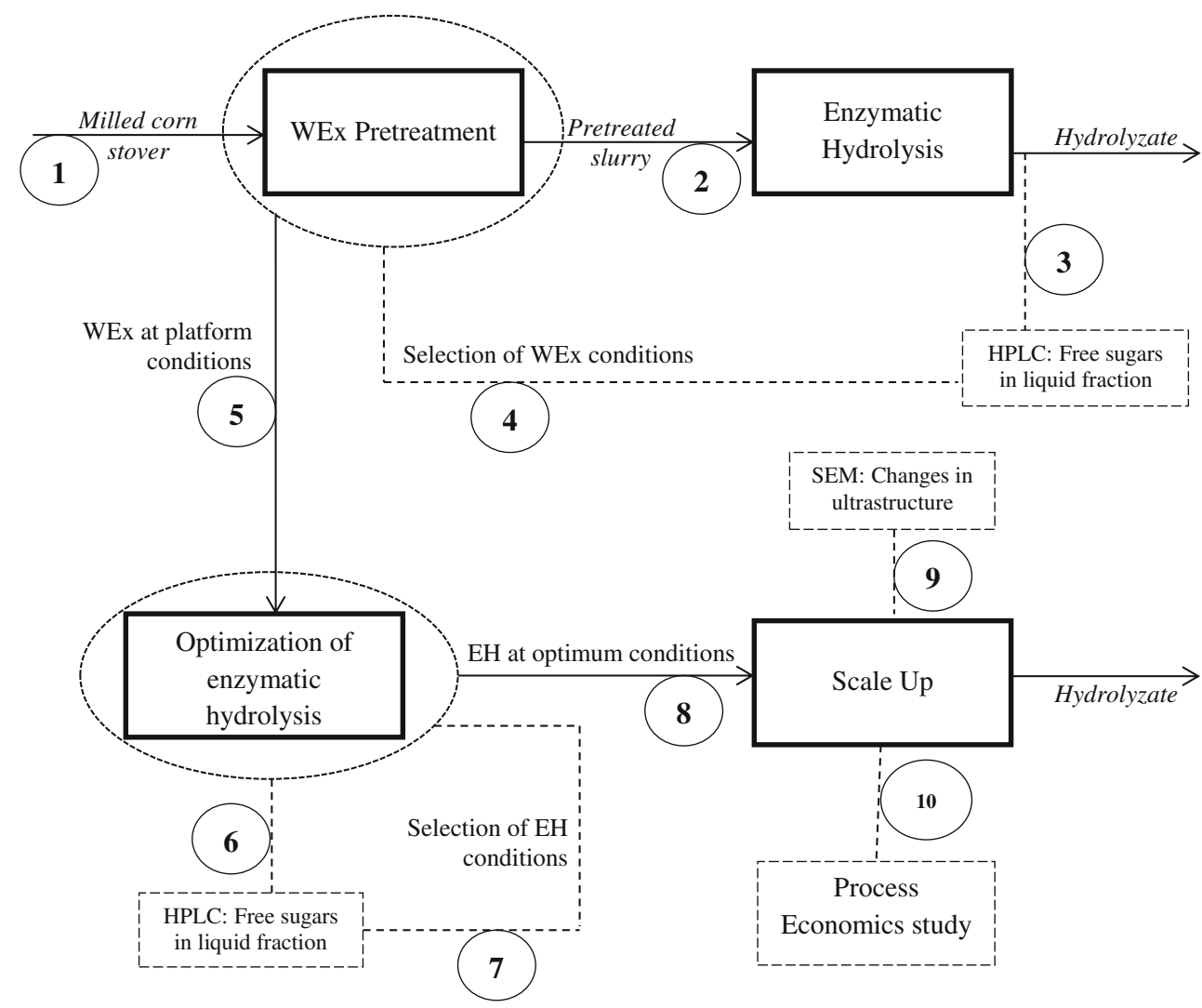

are shown in Table 1. Corn stover samples resulting from these pretreatment conditions are designated as CS-1 through CS-12. The 10-L WEx reactor was loaded with raw corn stover and water in proportions resulting in a total slurry of $5 \mathrm{~kg}$ with $25 \% \mathrm{SC}$. After closing the reactor, oxygen was introduced into the reactor at pressures ranging from 2 to 6 bar. After introducing the oxygen, the pretreatment reactor was heated to temperatures varying from 160 to $180{ }^{\circ} \mathrm{C}$ with residence times at the desired temperature between 15 and $25 \mathrm{~min}$ (heating time, about $5 \mathrm{~min}$ ). At the end of pretreatment reaction time, the pretreated biomass was flashed into a $100-\mathrm{L}$ flash tank. The slurry was used for the optimization of enzymatic hydrolysis experiment ("Hydrolysis Testing"), and a small portion of the slurry was kept for solid and liquid analysis.

\section{Hydrolysis Testing}

The pretreated slurries from 12 different runs were hydrolyzed using Cellic ${ }^{\circledR}$ CTec2 with $40 \mathrm{mg} \mathrm{EP} / \mathrm{g}$ glucan to investigate the maximum digestibility. A total of $50 \mathrm{~g}$ of well-mixed pretreated slurry with $25 \%$ SC was taken for enzymatic hydrolysis. The enzymatic hydrolysis of the pretreated samples was performed at $\mathrm{pH} 5$ and $50{ }^{\circ} \mathrm{C}$ for $72 \mathrm{~h}$ in $125-\mathrm{mL}$ shake flasks. In order to overcome the mixing challenges of $25 \% \mathrm{SC}$ in the Erlenmeyer shake flasks, the pretreated samples were diluted to $20 \%$ SC using $0.1 \mathrm{M}$ sodium citrate buffer. Maximum care was taken to ensure that the solid/liquid ratio was maintained during sampling using intense mixing. The pretreated sample with the highest sugar concentration and the minimal concentration of sugar degradation products was selected for the enzymatic hydrolysis optimization studies. Experiment for the enzyme optimization was then designed as described in "Optimization of Enzymatic Hydrolysis."

Table 1 Pretreatment conditions for WEx of $25 \%$ DM used in the present study

\begin{tabular}{llll}
\hline $\begin{array}{l}\text { Sample } \\
\text { number }\end{array}$ & $\begin{array}{l}\text { Reaction } \\
\text { temperature }\left({ }^{\circ} \mathrm{C}\right)\end{array}$ & $\begin{array}{l}\text { Residence } \\
\text { time }(\mathrm{min})\end{array}$ & $\begin{array}{l}\text { Oxygen } \\
\text { pressure (bar) }\end{array}$ \\
\hline CS-1 & 160 & 15 & 4 \\
CS-2 & 160 & 20 & 2 \\
CS-3 & 160 & 20 & 6 \\
CS-4 & 160 & 25 & 4 \\
CS-5 & 170 & 15 & 2 \\
CS-6 & 170 & 15 & 6 \\
CS-7 & 170 & 20 & 4 \\
CS-8 & 170 & 20 & 5.5 \\
CS-9 & 170 & 25 & 2 \\
CS-10 & 180 & 15 & 4 \\
CS-11 & 180 & 20 & 2 \\
CS-12 & 180 & 20 & 6 \\
\hline
\end{tabular}


The glucose yield is determined by Eq. (1) as described below:

$\%$ Yield $=\frac{\left(\text { Glu }_{\mathrm{EH}, \mathrm{L}}\right)}{1.111 \times F_{\text {cellulose } \mathrm{RB}} \times(\text { ini.sol })} \times 100$

where $\left(\mathrm{Glu}_{\mathrm{EH}, \mathrm{L}}\right)$ is the glucose concentration (grams per liter) in enzymatic hydrolyzate liquid, $F_{\text {cellulose }_{\mathrm{RB}}}$ is the fraction of cellulose in the raw biomass as determined by compositional analysis, and (ini.sol) is the initial solid concentration (grams per liter) at which the enzymatic hydrolysis was performed.

\section{Optimization of Enzymatic Hydrolysis}

A $2^{2}$ central composite design was used to optimize the enzymatic hydrolysis conditions. The statistical software Minitab (version 6.0, Minitab Inc., PA, USA) was used to generate the design of experiment, perform the statistical analysis, and develop the regression model. An enzyme loading of 5 to $40 \mathrm{mg} \mathrm{EP} / \mathrm{g}$ glucan and SC 5 to $20 \%$ were chosen as the independent variables. Fourteen experimental runs with six center points were conducted to evaluate the effect of enzyme loading and SC on glucose yield after enzymatic hydrolysis. Table 2 shows the design matrix and glucose yield response of the experiment. Data obtained from experimental runs were then analyzed according to the response surface regression and then fit to a second-order polynomial equation (Eq. (2)).

$Y_{i}=\beta_{0}+\sum_{i=2}^{n} \beta_{i} \chi_{i}+\sum_{i=2}^{n} \beta_{i i} \chi_{i}^{2}+\sum_{i=1}^{n-1} \sum_{j=i+1}^{n} \beta_{i j} \chi_{i} \chi_{j}$ where $Y_{i}$ is the response value, $\beta_{0}$ is the constant coefficient, $\beta_{i}$ is the linear coefficients, $\beta_{i j}(i$ and $j$ ) is the interaction coefficients, $\beta_{i i}$ is the quadratic coefficients, and $\chi_{i}$ is the variables. Analysis of variance (ANOVA) was used to estimate the significance of single factors, factors' square, and interaction of factors. The relationship between dependent and independent variables was further determined by the response surface plot.

\section{Analytical Methods}

A portion of the slurries obtained after WEx pretreatment and enzymatic hydrolysis were separated into solid and liquid fractions using a bench-top centrifuge (Eppendorf, Model $5804,8,000 \mathrm{rpm}, 10 \mathrm{~min}$ ). The liquid portion was then decanted and filtered through a $0.45 \mu \mathrm{m}$ syringe filter, and solids were washed and dried at $30^{\circ} \mathrm{C}$ for $48 \mathrm{~h}$. Free sugars in the liquid portion were analyzed using a Bio-Rad (Hercules, CA, USA) Aminex HPX-87P column with RI detector, operating at $83^{\circ} \mathrm{C}$ with Milli-Q water (Barnstead Nanopure, USA) as an eluent with a flow rate of $1.0 \mathrm{~mL} / \mathrm{min}$. The composition of the solid fraction was determined as per established NREL method [14].

\section{Scanning Electron Microscopy}

The morphological features of raw, pretreated, and enzymatically treated corn stover were observed by scanning electron microscopy (SEM) (S-570, Hitachi Ltd., Japan) at an acceleration voltage of $10 \mathrm{kV}$. SEM was conducted under high vacuum to improve the conductivity of the samples and the resolution of the SEM micrographs.
Table 2 Design of experiments for determining the optimal conditions of enzymatic hydrolysis using response surface methodology with predicted and experimental response

\begin{tabular}{|c|c|c|c|c|c|c|}
\hline \multirow[t]{2}{*}{ Run order } & \multicolumn{2}{|c|}{ Variables } & \multicolumn{2}{|c|}{ Coded levels } & \multirow{2}{*}{$\begin{array}{l}\text { Experimental } \\
\text { glucose yield (\%) }\end{array}$} & \multirow{2}{*}{$\begin{array}{l}\text { Predicted glucose } \\
\text { yield }(\%)\end{array}$} \\
\hline & $\begin{array}{l}\text { TS }(\%) \\
\chi_{1}\end{array}$ & $\begin{array}{l}\text { Protein (mg/g glucan) } \\
\chi_{2}\end{array}$ & $\chi_{1}$ & $\chi_{2}$ & & \\
\hline EH-1 & 5.00 & 5.00 & -1 & -1 & 58.13 & 57.54 \\
\hline EH-2 & 20.00 & 5.00 & 1 & -1 & 62.14 & 61.47 \\
\hline EH-3 & 5.00 & 40.00 & -1 & 1 & 77.12 & 78.90 \\
\hline EH-4 & 20.00 & 40.00 & 1 & 1 & 100.00 & 101.70 \\
\hline EH-5 & 12.50 & 22.50 & 0 & 0 & 87.21 & 90.28 \\
\hline EH-6 & 12.50 & 22.50 & 0 & 0 & 89.11 & 90.28 \\
\hline EH-7 & 12.50 & 22.50 & 0 & 0 & 90.07 & 90.28 \\
\hline EH-8 & 5.00 & 22.50 & -1 & 0 & 84.41 & 83.22 \\
\hline EH-9 & 20.00 & 22.50 & 1 & 0 & 97.62 & 96.59 \\
\hline EH-10 & 12.50 & 5.00 & 0 & -1 & 60.78 & 62.04 \\
\hline EH-11 & 12.50 & 40.00 & 0 & 1 & 96.31 & 92.83 \\
\hline EH-12 & 12.50 & 22.50 & 0 & 0 & 89.75 & 88.13 \\
\hline EH-13 & 12.50 & 22.50 & 0 & 0 & 91.68 & 88.13 \\
\hline EH-14 & 12.50 & 22.50 & 0 & 0 & 85.18 & 88.13 \\
\hline
\end{tabular}




\section{Results and Discussions}

\section{Raw Material}

The chemical composition of corn stover as determined using standard NREL protocols ("Analytical Methods") showed the following compositions: glucan $38.67 \%( \pm 0.12)$, xylan $25.21 \%( \pm 0.03)$, galactan $1.83 \%( \pm 0.03)$, arabinan $2.85 \%$ $( \pm 0.05)$, mannan $0.38 \%( \pm 0.16)$, Klason lignin $17.52 \%$ $( \pm 0.14)$, acid-soluble lignin $1.50 \%( \pm 0.01)$, ash $2.57 \%$ $( \pm 0.08)$, and acetate $4.34 \%( \pm 0.01)$ on dry basis. The composition analysis was performed in duplicates, and numbers shown are the average and the standard error is shown within the parentheses. The composition of raw material was used to calculate the glucose yields (percent) in the experiments.

\section{Selection of Platform WEx Pretreatment Conditions}

The amount of sugars released in the liquid phase after WEx pretreatment at 12 different conditions is shown in Fig. 2a. The amount of free sugars (glucose, xylose, and arabinose) released after WEx varied between 11.34 and $40.62 \mathrm{~g} / \mathrm{L}$.
During the hydrolysis testing, the amount of free sugars released varied between 77.16 and $130.94 \mathrm{~g} / \mathrm{L}$ (Fig. 2b). The amount of sugar degradation products (HMF and furfural) along with acetate (released from hemicellulose) generated during WEx varied between 3.79 and $12.79 \mathrm{~g} / \mathrm{L}$, whereas, during the enzymatic hydrolysis, their concentration varied between 6.50 and $15.49 \mathrm{~g} / \mathrm{L}$. The increase in HMF and furfural concentration during enzymatic hydrolysis is attributed to continued sugar degradation at a slower rate during enzyme hydrolysis. Interestingly, the pretreated sample CS-8 $\left(170{ }^{\circ} \mathrm{C}\right.$, $20 \mathrm{~min}, 5.5$ bar oxygen) released lower sugars during pretreatment $(16.44 \mathrm{~g} / \mathrm{L})$ as compared to other pretreated samples which released maximum sugars during enzyme hydrolysis $(130.94 \mathrm{~g} / \mathrm{L})$. These results are probably due to the fact that more oligomers were found in this sample (CS-8) due to a better opening of the structure (loosening of linkages between macromolecules in the cell wall). This is in agreement with previous studies by Ladisch et al. where they found that the optimal pretreatment conditions correlate with the oligosaccharides and not the monosaccharides released during pretreatment [15]. Sample CS-8 after pretreatment showed monomeric glucose $(2.97 \mathrm{~g} / \mathrm{L})$, xylose $(11.16 \mathrm{~g} / \mathrm{L})$, arabinose
Fig. 2 Sugars released after a WEx at 12 different pretreatment conditions and $\mathbf{b}$ enzymatic hydrolysis using $40 \mathrm{mg} \mathrm{EP} / \mathrm{g}$ of glucan. The error bars in the plot show the standard deviation
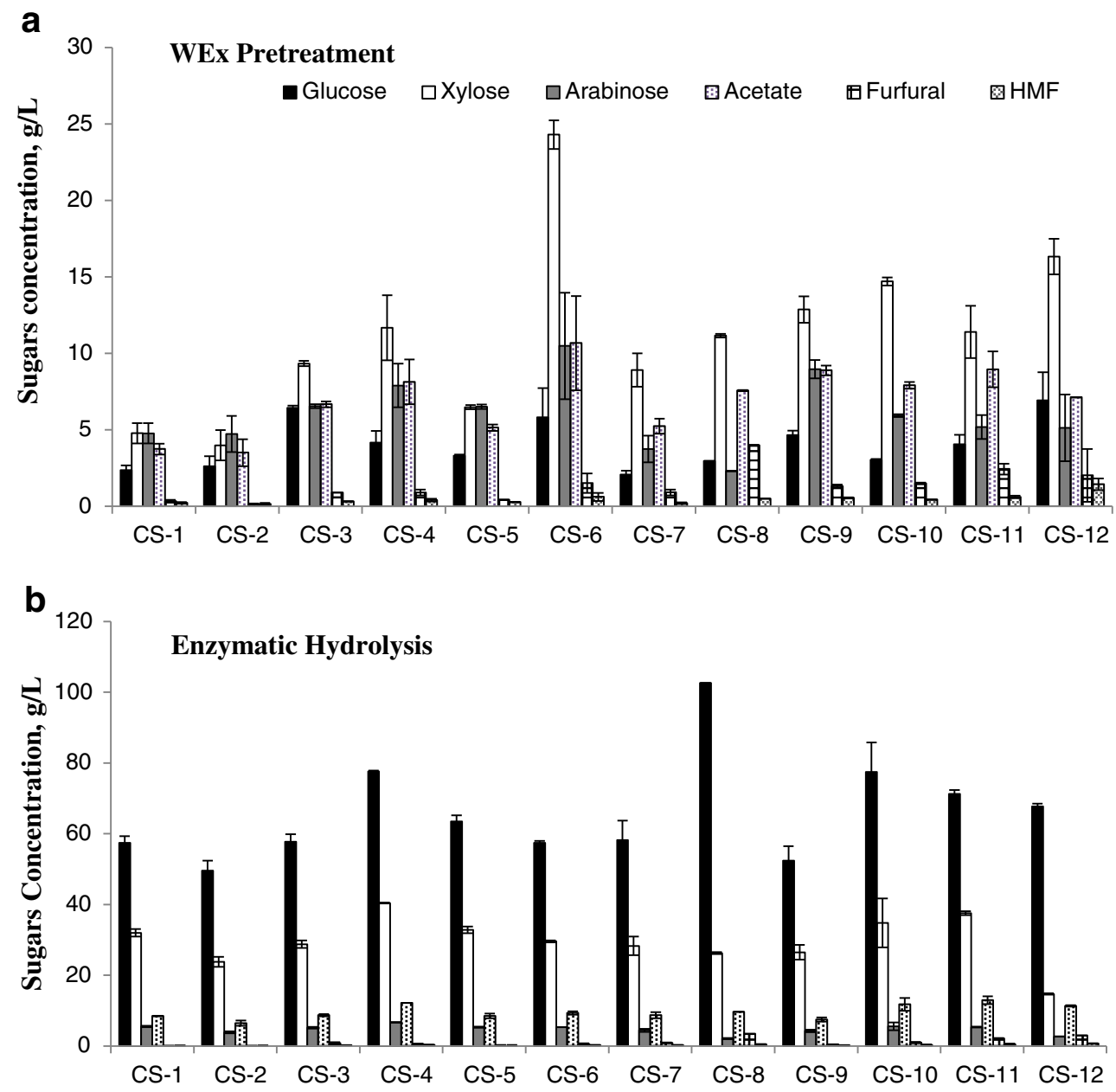
$(2.31 \mathrm{~g} / \mathrm{L})$ and, after enzymatic hydrolysis, showed highest concentration of glucose monomers $(102.61 \mathrm{~g} / \mathrm{L})$, xylose monomers $(26.25 \mathrm{~g} / \mathrm{L})$, and arabinose $(2.08 \mathrm{~g} / \mathrm{L})$, which gives amonomeric glucose yield of $81 \%$ compared to the glucan concentration of the corn stover. The amount of degradation products in sample CS-8 after pretreatment was $3.99 \mathrm{~g} / \mathrm{L}$ for HMF, $0.50 \mathrm{~g} / \mathrm{L}$ for furfural, and $7.57 \mathrm{~g} / \mathrm{L}$ for acetate. The amount of degradation products after enzymatic hydrolysis was $3.4 \mathrm{~g} / \mathrm{L}$ for HMF, $0.46 \mathrm{~g} / \mathrm{L}$ for furfural, and $9.6 \mathrm{~g} / \mathrm{L}$ for acetate. The amount of lignin solubilized during pretreatment was $8 \%$, which remained unchanged during enzymatic hydrolysis. Sample CS- 8 was, therefore, chosen as platform WEx pretreatment conditions for enzyme optimization study as it released highest sugars and minimal sugar degradation products.

\section{Enzyme Optimization}

\section{Optimization of Enzymatic Hydrolysis Parameters}

Full-factorial statistical model was developed by the statistical software Minitab 16. Table 2 shows coded and uncoded variables along with the experimental and model-predicted response. Low, midpoint, and high levels were coded as -1 , 0 and +1 , respectively. The response of glucose yield after $72 \mathrm{~h}$ of enzymatic hydrolysis from all 14 runs as a function of cellulase loading (mg EP/g glucan) and SC was evaluated in $\mathrm{CCD}$. The interaction between response and variables was evaluated by response surface after $12,24,48$, and $72 \mathrm{~h}$ (Fig. 3). Each response surface plot confirmed the interactions existing between the variables and glucose yield. As shown in Table 2, the experimental glucose yield matched closely with the model-predicted glucose yield with a regression coefficient of $97.68 \%$.

Minitab 16 was used to conduct ANOVA to evaluate individual and interactive effects of variables. Significance of coefficients of the model was analyzed. The results of the second-order response surface models for the glucose released during hydrolysis are presented in the form of ANOVA in Table 3. Equation (3) describes the second-order polynomial model to evaluate the relationship between variables and glucose yield of enzymatic hydrolysis.

$$
\begin{aligned}
Y= & 46.0929+0.2501 \chi_{1}+2.3183 \chi_{2}-0.0067 \chi_{1}^{2} \\
& -0.0420 \chi_{2}^{2}+0.0359 \chi_{1} \chi_{2}
\end{aligned}
$$

In the above equation (Eq. (3)), $Y$ is the glucose yield after $72 \mathrm{~h}$ of hydrolysis, $\chi_{1}$ is $\mathrm{SC}$ (percent), and $\chi_{2}$ is enzyme loading (milligrams EP per gram glucan). The statistical significance of the model was evaluated by $F$ test for ANOVA, which confirmed that the regression was statistically significant. Temperature and $\mathrm{pH}$ were excluded from the optimization model because these factors had already been optimized as $50{ }^{\circ} \mathrm{C}$ and 5 , respectively (www.bioenergy.novozymes.com).

Statistical effect of SC and enzyme loading on glucose yield is shown in Table 3. As shown in Table 3, the coefficient of
Fig. 3 Response surface plot showing the impact of the interaction between substrate concentration (SC) and enzyme protein (EP) on monomeric glucose yields (GY) after a $12 \mathrm{~h}$, b $24 \mathrm{~h}, \mathbf{c} 48 \mathrm{~h}$, and d $72 \mathrm{~h}$ of enzymatic hydrolysis
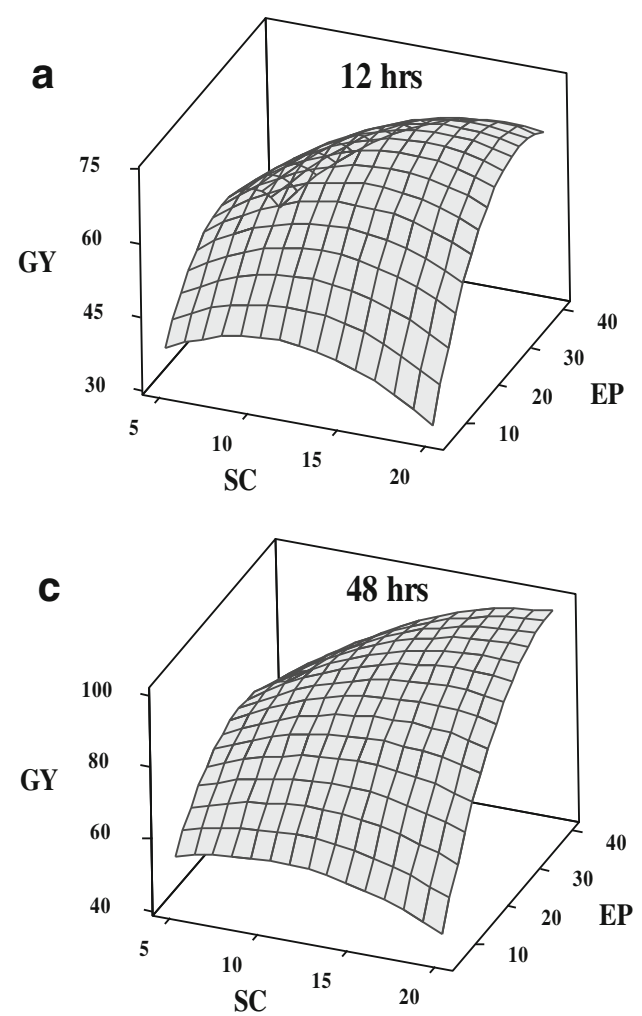
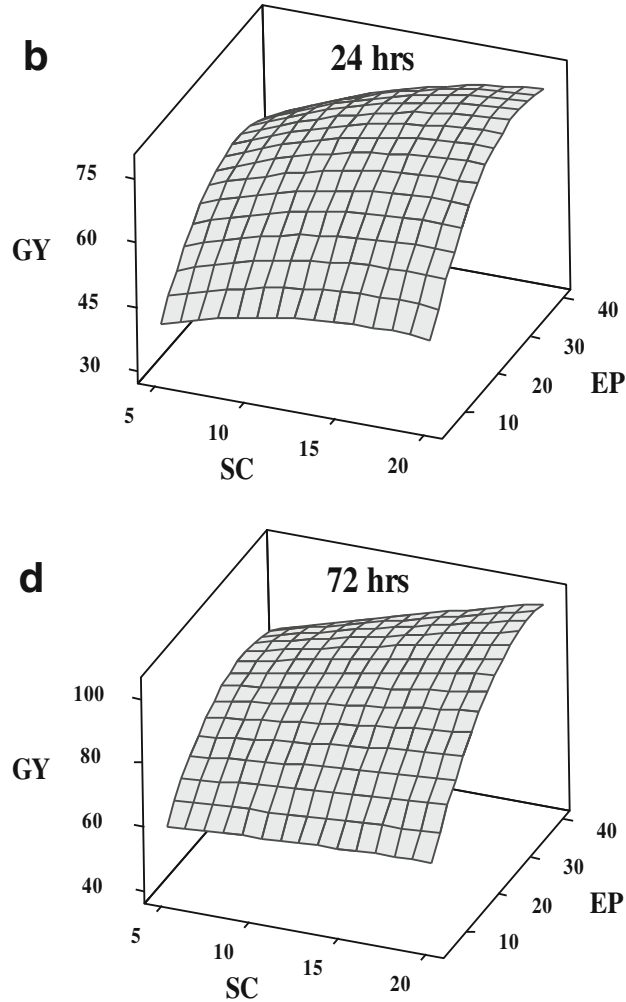
Table 3 ANOVA table for glucose yield

$R^{2}=97.68 \%, R^{2}$ (predicted $)=$ $85.94 \%, R^{2}$ (adjusted) $=95.69 \%$

\begin{tabular}{llrrrrc}
\hline Source of variation & $d f$ & Sum of squares & Mean square & $F$ ratio & $p$ value & Coefficient \\
\hline Regression & 5 & $2,309.63$ & 461.93 & 55.94 & 0.000 & 46.0929 \\
Linear & 2 & $1,690.35$ & 845.17 & 102.34 & 0.000 & - \\
$\quad$ SC (\%) & 1 & 268.00 & 268.00 & 32.45 & 0.000 & 0.2501 \\
$\quad$ EP (mg) & 1 & $1,422.34$ & $1,422.34$ & 172.24 & 0.000 & 2.318 \\
Square & 2 & 530.27 & 265.13 & 32.11 & 0.000 & - \\
$\quad$ SC (\%) $\times$ SC (\%) & 1 & 0.39 & 0.39 & 0.05 & 0.835 & -0.0067 \\
EP (mg) $\times$ EP (mg) & 1 & 450.15 & 450.15 & 54.51 & 0.000 & -0.0420 \\
Interaction & 1 & 89.02 & 89.02 & 24.05 & 0.013 & - \\
$\quad$ SC(\%) $\times$ EP (mg) & 1 & 89.02 & 89.02 & 24.05 & 0.013 & 0.0359 \\
Residual error & 7 & 57.81 & 8.26 & - & - & - \\
Lack of fit & 3 & 31.28 & 10.43 & 1.57 & 0.33 & - \\
Pure error & 4 & 26.52 & 6.63 & - & - & - \\
Total & 13 & $2,547.84$ & - & - & - & - \\
\hline
\end{tabular}

regression $\left(R^{2}\right)$ was calculated as $97.68 \%$, which indicated that the model is suitable to adequately represent the real relationships among the selected reaction variables. Highly adjusted $R^{2}$ $(95.69 \%)$ also showed the suitability of the model. Linear and squared terms of enzyme loading exerted a positive effect on the yield of glucose during enzymatic hydrolysis as the $p$ values were $<0.05$. Linear SC has been found to have a significant effect; however, there was no direct effect of squared SC. This can be explained by the heterogeneity of the pretreated sample. Interaction of both enzyme loading and SC has a significant effect $(p<0.05)$, which indicates cumulative effect of both factors on enzymatic hydrolysis.

The objective of the optimization was to achieve a glucose yield of at least $80 \%$. The SC and enzyme loading combination at which the highest desirability $(0.959)$ was obtained was chosen as the optimal conditions for the enzymatic hydrolysis with the predicted value of the response, $85.94 \%$. The optimal conditions for the enzymatic hydrolysis from the statistical analysis were found to be $20 \% \mathrm{SC}$ and $15 \mathrm{mg} \mathrm{EP} / \mathrm{g}$ glucan (about 5 FPU), which gave a glucose yield of $84 \%$ that is in agreement with the predicted response. Thus, we concluded that the model was valid and reliable in predicting the experimental results.

\section{Influence of SC and Enzyme Loading During Enzymatic Hydrolysis}

The significance of the quadratic coefficients of enzyme loading and SC for corn stover indicates a positive correlation between enzyme loading, SC, and hydrolysis yield. No noticeable mass transfer limitation was observed (due to high viscosity of the slurry) in contrast to previous studies [16, 17] as evident by high glucose yield. Optimal process conditions for enzymatic hydrolysis to high glucose included both high SC and low enzyme loading. This is a remarkable improvement over previous studies done with pretreated corn stover either at low SC $(<10 \%)$ or high enzyme loading $(>10 \mathrm{FPU}$, equivalent to $30 \mathrm{mg} \mathrm{EP} / \mathrm{g}$ glucan) to achieve higher cellulose conversion $[5,6,18,19]$. By increasing the SC, the glucose yield improved significantly. This lowers the cost of fermentation and eliminates the need for concentration of the hydrolysate before fermentation, which would add to the overall cost.

\section{Test at Scale-Up Conditions of Enzymatic Hydrolysis}

Under the optimal conditions (20\% SC, $15 \mathrm{mg} \mathrm{EP} / \mathrm{g}$ glucan, $\mathrm{pH} 5$, and $50{ }^{\circ} \mathrm{C}$ ), the model predicted a glucose yield of $84.8 \%$. The actual experiment yield was $84 \%$, which was in close agreement with the model's prediction, confirming the validity of the RSM model. A comparative study in $100-\mathrm{L}$ pilot scale was performed with the optimized hydrolysis condition (20\% SC, $15 \mathrm{mg} \mathrm{EP/g}$ glucan) and compared to the hydrolysis condition at which the maximum yield was obtained (20\% SC, $40 \mathrm{mg} \mathrm{EP/g}$ glucan). Glucose yield of 84 and $99 \%$ was attained at 15 and $40 \mathrm{mg} \mathrm{EP} / \mathrm{g}$ glucan, respectively.

\section{Scanning Electron Microscopy}

SEM was performed to understand the morphological changes for the corn stover samples when hydrolyzed at the determined enzyme loading ( $15 \mathrm{mg} \mathrm{EP} / \mathrm{g}$ glucan) versus the highest enzyme loading (40 mg EP/g glucan). Figure 4 shows SEM micrographs to elucidate the changes in the fibrillar structure of raw corn stover and after treatment (WEx and enzymatic hydrolysis). Corn stover (Fig. 4a) exhibited compact and highly ordered fibril structure covered with a wax layer, binding materials, and other deposits (common to herbaceous lignocellulosic biomass). Figure $4 \mathrm{~b}$ showed damages in the fibrillar structure as a result of WEx pretreatment. Degradation caused by the harsh pretreatment conditions was demonstrated by the appearance of exposed smooth cellulose surface, peeling, reticular areas, and interfibrillar splitting in the direction 
Fig. 4 Scanning electron micrograph of corn stover: a control, raw corn stover; $\mathbf{b}$ wetoxidized corn stover; c enzymatically treated corn stover using $15 \mathrm{mg} \mathrm{EP}$ at $20 \% \mathrm{SC}$; and d enzymatically treated corn stover using $40 \mathrm{mg}$ EP at $20 \%$ SC. Scale: $\mathbf{a}-\mathbf{d}=50 \mu \mathrm{m}$
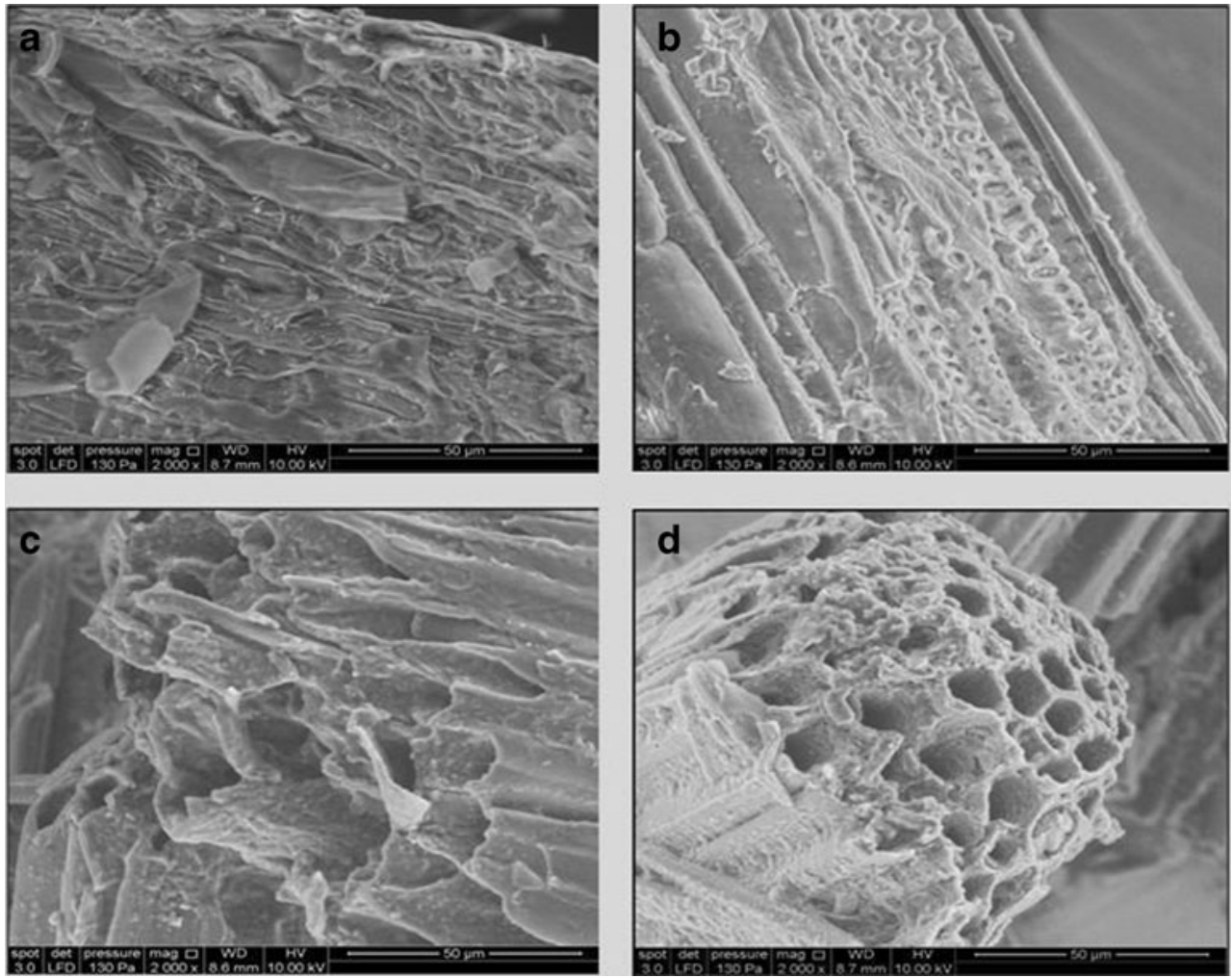

of the fiber axis. Despite these major changes after WEx, some conducting vessels and pits still remained intact, demonstrating the need for enzyme digestion. Panels $\mathrm{c}$ and $\mathrm{d}$ of Fig. 4 show the SEM images after enzymatic hydrolysis conducted at enzyme loading of 15 and $40 \mathrm{mg} \mathrm{EP} / \mathrm{g}$ glucan, respectively. Enzymatic hydrolysis caused the fibrous surface to be altered and enhanced the porosity induced by the WEx pretreatment. In both panels $\mathrm{c}$ and $\mathrm{d}$ of Fig. 4, degradation of fiber surface was significant, but the extent of degradation varied with the amount of enzyme protein added (and cellulase accessibility to fibers). With the determined optimal enzymes loading of $15 \mathrm{mg} \mathrm{EP} / \mathrm{g}$ glucan (Fig. 4c), longitudinal disintegration of

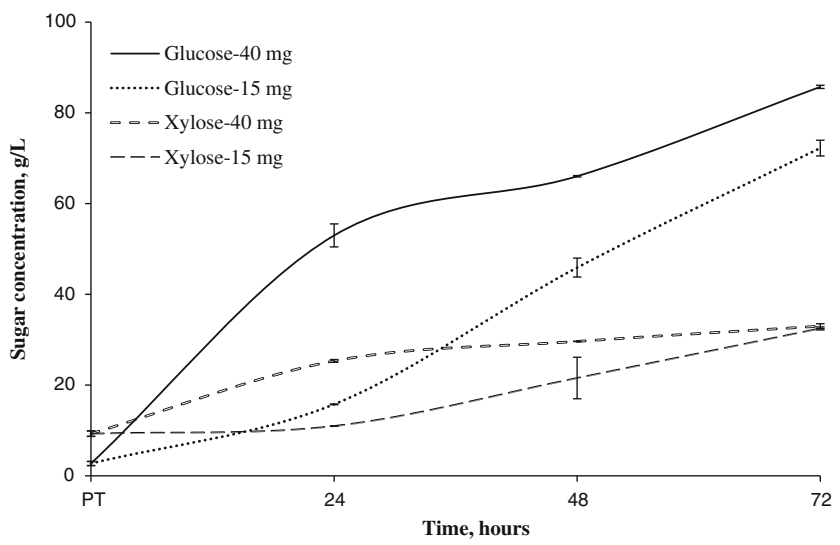

Fig. 5 Glucose and xylose concentration (grams per liter) at $20 \%$ substrate concentration and 40 and $15 \mathrm{mg}$ protein at pilot scale fibers and formation of fissures on the surface were observed and surface erosion was unevenly distributed, whereas with the increase in enzyme loading (Fig. 4d), uniform surface corrosion was observed. These observations lead to the conclusion that morphological differences between the corn stover samples hydrolyzed with 15 and $40 \mathrm{mg}$ EP/g glucan were noticeable but relatively minor compared to the fact that 2.7 times more enzyme was added in the last case (Fig. 5).

\section{Process Economics}

Figure 6 shows the effect of varying enzyme loadings and SC on glucose yields. With the increase in the enzyme loading and SC, high glucose yield was achieved but, at the same time,

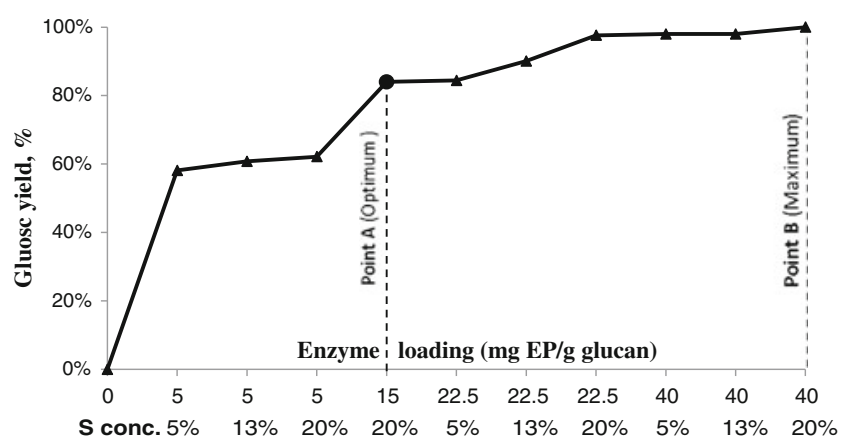

Fig. 6 Effect of enzyme loading and substrate concentration on glucose yield 
enzyme cost increased significantly due to the need for higher enzyme dosage. Due to unavailability of an exact price of Cellic ${ }^{\circledR} \mathrm{CTec} 2$, we found it more appropriate to use the relative cost savings derived from the quantity of enzymes used at the sweet spot for the economics modeling. Amount of enzymes (kilograms) was calculated from enzyme loading (milligrams enzyme protein per gram glucan) at respective substrate concentration for processing $1,000 \mathrm{~kg}$ of biomass slurry as basis as shown below.

$\begin{aligned} \text { Amount of enzymes }(\mathrm{kg})= & \text { Biomass slurry }(\mathrm{kg}) \times \operatorname{Substrate} \text { concentration }(\%) \times \text { Glucan }(\%) \\ & \times[\text { Enzyme loading }(\mathrm{mgEP} / \mathrm{g} \text { glucan }) / \mathrm{mgEP} / \mathrm{mlenzyme}] \times \text { Enzyme density }(\mathrm{g} / \mathrm{mL})\end{aligned}$

Using $210 \mathrm{mg} \mathrm{EP} / \mathrm{mL}$ of enzyme solution, enzyme density as $1.2 \mathrm{~g} / \mathrm{mL}$, SC $20 \%$, glucan $38.67 \%$, and enzyme loading at points A and B as 15 and $40 \mathrm{mg} \mathrm{EP} / \mathrm{g}$ glucan, respectively, the amount of enzyme calculated at points A and B was 6.51 and $17.37 \mathrm{~kg}$, respectively, to process $1,000 \mathrm{~kg}$ of biomass slurry. Glucose yields at points A and B were 84 and $99 \%$, respectively. At point A, our sweet spot, we observed a plateau, which suggests that further increase in enzyme loading and SC has little effect on the glucose yield, and therefore, we considered that point as optimal.

Comparing the relative difference in glucose yield and enzyme amount at points A and B, we found at the sweet spot (point A) a glucose yield that was $16 \%$ lower; however, $62.5 \%$ less enzymes were used, which would represent a significant saving compared to the optimal condition. Moreover, some enzymes from the enzymatic hydrolysis step remain functional during the subsequent fermentation process, and these enzymes will be capable of processing at least parts of the $16 \%$ of unconverted cellulose remaining after enzymatic hydrolysis into glucose. These findings agree with the past studies done by Shen and Agblevor [20], who suggested that the enzyme cost for complete hydrolysis (100\% conversion of cellulose to glucose) is prohibitive in achieving the economically viable commercialization of ethanol production.

\section{Conclusion}

WEx pretreatment and enzymatic hydrolysis at high SC were found to produce high glucose yield from corn stover even at low enzyme loadings. Experimental results showed that the most optimal and economically feasible condition for high yields of glucose (about $84 \%$ ) was obtained when corn stover was wetexploded at $170{ }^{\circ} \mathrm{C}$ for 20 min with 5.5 bar oxygen and subsequently enzymatically hydrolyzed at $20 \%$ SC and $15 \mathrm{mg} \mathrm{EP} / \mathrm{g}$ glucan. Significant enzyme cost saving can be achieved by accepting a glucose yield of about $80 \%$ compared to the full conversion of the glucan of corn stover.
Acknowledgments The authors gratefully acknowledge the financial support from the National Advanced Biofuels Consortium (NABC) and Department of Energy, USA (grant no. ZFT04064401). The authors would like to thank the Franceschi Microscopy and Imaging Center at Washington State University for SEM.

Open Access This article is distributed under the terms of the Creative Commons Attribution License which permits any use, distribution, and reproduction in any medium, provided the original author(s) and the source are credited.

\section{References}

1. Banerjee G, Scott-Craig J, Walton J (2010) Improving enzymes for biomass conversion: a basic research perspective. Bioenergy Res 3: $82-92$

2. Lynd LR, Laser MS, Bransby D, Dale BE, Davison B, Hamilton R, Himmel M, Keller M, McMillan JD, Sheehan J, Wyman CE (2008) How biotech can transform biofuels. Nat Biotechnol 26:169-172

3. Kristensen J, Felby C, Jorgensen H (2009) Yield-determining factors in high-solids enzymatic hydrolysis of lignocellulose. Biotechnol Biofuels 2:11

4. Kaar WE, Holtzapple MT (2000) Using lime pretreatment to facilitate the enzymic hydrolysis of corn stover. Biomass Bioenergy 18: 189-199

5. Kim S, Holtzapple MT (2005) Lime pretreatment and enzymatic hydrolysis of corn stover. Bioresour Technol 96:1994-2006

6. Kim TH, Lee YY (2005) Pretreatment of corn stover by soaking in aqueous ammonia. Appl Biochem Biotechnol 121:1119-1131

7. Bura R, Chandra R, Saddler J (2009) Influence of xylan on the enzymatic hydrolysis of steam-pretreated corn stover and hybrid poplar. Biotechnol Progr 25:315-322

8. Zhu JY, Zhu W, Obryan P, Dien B, Tian S, Gleisner R, Pan XJ (2010) Ethanol production from SPORL-pretreated lodgepole pine: preliminary evaluation of mass balance and process energy efficiency. Appl Microbiol Biotechnol 86:1355-1365

9. Yang J, Zhang XP, Yong QA, Yu SY (2011) Three-stage enzymatic hydrolysis of steam-exploded corn stover at high substrate concentration. Bioresour Technol 102:4905-4908

10. Ahring BK, Munck J (2009) Method for treating biomass and organic waste with the purpose of generating desired biologically based products. US Patent 0178671

11. Ahring BK, Jensen K, Nielsen P, Bjerre AB, Schmidt AS (1996) Pretreatment of wheat straw and conversion of xylose and xylan to ethanol by thermophilic anaerobic bacteria. Bioresour Technol 58: $107-113$ 
12. Adney B, Baker J (2008) Measurement of cellulase activities. National Renewable Energy Laboratory, Golden

13. Rana D, Rana V, Ahring BK (2012) Producing high sugar concentrations from loblolly pine using wet explosion pretreatment. Bioresour Technol 121:61-67

14. Sluiter A, Hames B, Ruiz R, Scarlata C, Sluiter J, Templeton D, Crocker D (2008) Determination of structural carbohydrates and lignin in biomass. National Renewable Energy Laboratory, Golden

15. Wyman CE, Dale BE, Elander RT, Holtzapple M, Ladisch MR, Lee YY, Mitchinson C, Saddler JN (2009) Comparative sugar recovery and fermentation data following pretreatment of poplar wood by leading technologies. Biotechnol Prog 25:333-339

16. Ingesson H, Zacchi G, Yang B, Esteghlalian AR, Saddler JN (2001) The effect of shaking regime on the rate and extent of enzymatic hydrolysis of cellulose. J Biotechnol 88:177182

17. Wen ZY, Liao W, Chen SL (2004) Hydrolysis of animal manure lignocellulosics for reducing sugar production. Bioresour Technol 91: 31-39

18. He X, Miao YL, Jiang XJ, Xu ZD, Ouyang PK (2010) Enhancing the enzymatic hydrolysis of corn stover by an integrated wet-milling and alkali pretreatment. Appl Biochem Biotechnol 162:2449-2457

19. Varga E, Szengyel Z, Reczey K (2002) Chemical pretreatments of corn stover for enhancing enzymatic digestibility. Appl Biochem Biotechnol 98:73-87

20. Shen J, Agblevor FA (2008) Optimization of enzyme loading and hydrolytic time in the hydrolysis of mixtures of cotton gin waste and recycled paper sludge for the maximum profit rate. Biochem Eng $\mathrm{J}$ 41:241-250 